\title{
How Do Second Grade Students in Primary Schools Use and Perceive Tablets?
}

\author{
Halit Karalar ${ }^{1, *}$, Sabri Sidekli ${ }^{2}$ \\ ${ }^{1}$ Department of Computer Education and Instructional Technology, Faculty of Education, Muğla Sitkı Koçman University, Turkey \\ ${ }^{2}$ Department of Elementary Education, Faculty of Education, Muğla Sitkı Koçman University, Turkey
}

Copyright $(2017$ by authors, all rights reserved. Authors agree that this article remains permanently open access under the terms of the Creative Commons Attribution License 4.0 International License

\begin{abstract}
In the life of students who are named digitally born in this era, tablets have a crucial role. The aim of this study, which is designed as a case study model, is to determine the use of tablet by second grade students and it aims to reveal their perception towards tablets via metaphors. 63-second grade students are participated in this study in spring semester in 2015-2016 in Muğla regarding convenient sampling method. The data for the study is gathered via a written form including students' background information and open-ended questions that is developed by the researchers of this study. The data are analyzed via content analysis methods. As a result of the study, it is determined that parents mostly restrict the use of tablets by their children; moreover students prefer reading printed books to digital ones and they prefer playing with their friends in parks to playing games in their tablets; additionally it is determined that the students in this study use tablets for the aim of playing games, searching, watching videos and doing homework, however they rarely use tablets in order to read books, listen to music and take photographs. Besides, it is seen that the students have a positive aspect for using tablets, and they develops 24 metaphors under 4 main themes.
\end{abstract}

Keywords Primary Schools, Second Grade Students, Technology Integration, Tablet

\section{Introduction}

Nowadays, internet and mobile technologies have become an indispensable part of daily life. Among the mobile technologies, no doubt that tablet computers, shortly tablet, is one of the most frequently used ones. As considering the rate of tablet sales, it is assumed that tablet sales will preclude computer sales in the near future. Gartner [1] estimates that 233 billion computers and 244 billion tablets will be sold in 2017, whereas Statista [2] thinks that 123 billion computers will be sold while 407 billion tablets will be sold in 2017. In the estimations of two companies in terms of tablet sales, it is pointed that tablet sales will preclude computer sales. All of these estimations reveal that tablets will supplant computers in the near future. In a study, it is stated that more than $60 \%$ of children who are under 3 years interact with different technologies and many of them can use tablets, computers and internet [3]. Accordingly, it can be said that internet and tablets might be indispensable technological instruments for students in the future.

Tablets can be defined as a notebooks by which can be written on touch-operated screen via stylus and can be recognized handwritings [4]. With their properties as having all characteristics of computers, being portable and light like smart phones, can be used whenever and wherever the users want, having an easy usage, having a touch-operated screens and having a stylus; tablets fill a gap of smart phones and computers $[5,6]$.

Even if tablets have not been developed for education, they have succeeded to get attention of educators. Tablets are resembled virtual classrooms consisting of students' books, homework, notes and sources [7]. Additionally, tablets that are identified as green technology [5] reduce the use of paper for both students and teachers. Thanks to some suitable applications in tablets, teachers can send digital learning resources (documents, videos, voices and supportive sources) and homework; students can do homework via tablets and teachers can give feedback through tablets and they can also catch the progress of their students thanks to tablets; lastly an interactive teaching environment can be created by teachers [5]. Due to these properties, the use of tablets in education has become popular in recent years.

It is stated that tablets can contribute the educational events via supplying simulations, camera and microphone, e-book or e-notebook, interactive teaching environment and simultaneous feedback [7]. In many studies, accordingly, the advantages of tablets are determined as increasing students' motivation, giving simultaneous feedback, being portable, supplying teaching in everywhere and every time, enhancing teaching and learning processes, increasing independent learning and supplying an interactive atmosphere for students $[8,9,10,11,12,7,6,13,14]$. Although there are a 
number of advantages of tablets, in many studies, some disadvantages of using tablets are introduced. As for the disadvantages of using tablets in education; the lack of applications that can be used in classrooms [15], some technical and management problems [12], the lack of knowledge on using tablets for education and causing distractibility for students [11] are introduced by some researchers.

In many countries, in order to conduct reforms in education, solve problems in educational systems, create more productive and active school environment, train student to gain $4 \mathrm{C}$ (creativity, communication, collaboration, critical thinking) skills that is defined for $21^{\text {st }}$ century, increase motivation and performance, make easy learning and make actual learner-centered pedagogical aspects [16, 17], technology integration to education has been seen as a solution and projects that have huge budgets have been carried out by those countries. In those projects, tablets have a crucial role because the properties mentioned above. In the big technology integration projects in which tablets are used, a project namely "One Tablet PC Per Child" that has been conducted by Thailand Government can be given as an example. In this project, 800.000 tablets were delivered for each one of the students in the first grade in 2012 [18]. Another important Project has been carried out in our country as the name of FATIH Project (Improving Opportunities and Enhancing Technology). In this project, background of the classrooms and smart boards were installed; additionally 13.800 tablets were delivered to $9^{\text {th }}$ grade students and their teachers except for vocational high schools in 2011; 737.800 tablets were delivered in 2014 and finally 1.437 .800 tablets were delivered in 2015 [19]. In the following parts of this project, it is planned to deliver tablets to students in primary and secondary schools [11].

There are some studies have been carried out in order to be useful for students in terms of using tablets in early years of their lives. In the studies carried out in primary schools, it is seen that there is not a mean difference in reading printed books and digital books [20], however students who are drawing with pencils and papers have more drawing abilities than the others who are drawing on tablets [21], additionally using tablets positively affect emotional, psychomotor and socio-cultural progress of students and it may motivate students in their teaching environment [13]; tablets also motivate students and it increases independent learning [6]; yet there is not a mean difference in terms of students writing abilities [22] and students are seen as eager to use tablets and they can easily motivated then they are wanted to use tablets and they can study with tablets more than their books [12]. Moreover, in these studies, it is realized that using tablets can much more improve mathematical abilities than traditional ways [23] and it is seen that students who do their homework with the help of tablets feel more confident and they are more responsible for their learning and independent learning environment can be improved as in this way [24].

It is accepted that children who are named as digitally born are given birth in a digital world in which their ideas, attitudes and actions are shaped [25]. In this era, children's ideas, getting knowledge and the process of acquiring information are seen different than previous generations who are named as digital aboriginals [25]. Furthermore, students in this era can reach information in a digital atmosphere and they can do multitasks easily [26, 25]. For this reason, it is seen as important to supply a technological environment for students from the beginning of their educational lives. Although it is stated that students begin to have abilities to use internet in the third grade [27], in some studies, it is indicated that $60 \%$ of children begin to use internet and technological devices when they are under 3 years old and they are interacted with technology in these years [3]. In order to use tablets in a safe and moral way, the role of primary school teachers have been seen as important; this importance can be highlighted via tablet technology integration to classrooms [28]. In order to integrate tablets to classrooms, it is important to determine how and why students use tablets currently and their perceptions on using tablets should be determined, too [15]. These kinds of studies can be seen as helpful some projects such as FATIH Project and these are also helpful for strategies and methods in technology integration processes. However, when the literature is reviewed, it is seen that there has not been so much studies in this field. It is thought that this study can fill a gap in this field.

\subsection{Aim}

The aim of this study is to determine the use of tablets for the second grade students and it aims to reveal students' perceptions on tablets via metaphors. With regard to these aims, the following questions are tried to be answered.

1. What are the students' positions on using tablets?

a. What the position of having a tablet?

b. Is the use of tablet restricted?

c. Do students prefer reading books via their tablets?

d. Do students prefer playing in the garden to playing tablets?

2. What the perceptions of students on using tablets?

\section{Methodology}

\subsection{Research Design}

As pointing the aims of this study, this study is designed as a case study model. One of the most basic reasons for selecting this model is describing the situation in a current way. According to Karasar [29], case study model is effective while describing a situation whether in the past or present. Another reason of selecting case study model is analyzing the current situations with their reasons. Fraenkel, Wallen and Hyun [30] describe the case study model as a research model that is helpful to identify the characteristics of people or groups and helpful for examining in a detailed way. 


\subsection{Participants}

As for the participants of this study, 63-second grade students in primary schools in Muğla that is dependent on Muğla Directorate of National Education were selected in the spring semester of 2015-2016 academic year regarding convenient sampling method. The students were $7(10 \%), 8$ $(73 \%)$ and $9(11 \%)$ years old and 27 of them were female $(43 \%)$ and 36 of them were male $(57 \%)$. The reason of selecting second grade students is based on the idea that they are the younger students who can introduce themselves in a literary way. On this decision, it is effective to conduct an interview with teachers who train in second grade and they stated that "students have a tendency to explain everything in a detailed way in these years". Based on the school administration records, parents' socio-economic and educational status were found above the average. Students participated in the study were reported as academically successful and socially interactive.

\subsection{Data Collection Instruments}

In order to collect data, a written form including students' background information and open-ended questions was developed by the researchers. The two open ended questions in the form in order to identify the way of using tablet in students' daily lives were presented as, "I use tablet for the aim of ............" and in order to identify some metaphors, some questions such as "I stimulate tablets to ..............., because ........................" for the aim of this study. As for consultation, an expert in the Department of Computer Education and Instructional Technology and another expert in the Department of Primary School Education; additionally two primary school teachers were consulted for the items in the form. Before the main study, the form was piloted with five students in second grade and it was observed that the items were easily completed by the students.

\subsection{Data Analysis}

For the students' background information, descriptive statistics were used. The data obtained from open-ended questions were also analyzed with content analysis method. During the content analysis completed via NVivo 11 program, some codes (in-vivo code) were organized as a result of the students' answers and those codes were covered under the main themes. The content analysis was completed separately by the researchers and it was seen that the codes determined for this study were covered each other in $90 \%$.

\section{Findings}

\subsection{The Situation of Using Tablets by Students}

\subsubsection{Having a Tablet}

58 students $(92 \%)$ have tablets at home and 5 of the students $(8 \%)$ have not a tablet. All of the students who have a tablet stated that they could install some applications on their tablets.

\subsubsection{The Restriction of Using Tablet}

All of the students stated that they needed a permission to use tablets. The level of parents' restriction on using tablets is given in Table 1. According to this table, 6 of the students $(10 \%)$ stated that they could use tablets every day; however 4 of the students (7\%) pointed that they could use tablet for one day in a week; finally 48 of the students $(83 \%)$ stated that they could use their tablets just at weekends. The children were informed about the time of using the tablets by their parents.

Table 1. The parents' restrictions on using tablets

\begin{tabular}{|c|c|c|c|}
\hline \multirow{4}{*}{ Day } & Duration & $\mathrm{n}$ & $\%$ \\
\hline \multirow{4}{*}{ Weekend } & 1 hour & 19 & 40 \\
\cline { 2 - 4 } & Unlimited & 1 & 2 \\
\cline { 2 - 4 } & 30 minutes & 18 & 38 \\
\cline { 2 - 4 } & 9 hours & 1 & 2 \\
\cline { 2 - 4 } & 5 hours & 3 & 6 \\
\cline { 2 - 4 } & 2 hours & 6 & 13 \\
\hline \multirow{3}{*}{ One day in a week } & & 48 & 100 \\
\cline { 2 - 4 } & 30 minutes & 3 & 75 \\
\cline { 2 - 4 } & 1 hour & 1 & 25 \\
\hline \multirow{3}{*}{ Always } & 1 hour & 3 & 100 \\
\cline { 2 - 4 } & 2 hours & 2 & 33 \\
\cline { 2 - 4 } & Unlimited & 1 & 17 \\
\hline
\end{tabular}

Another restriction that was determined by the parents was about the duration of using tablets. 19 of the students (40\%) who could use tablets at weekends stated that they were permitted to use their tablets just for 1 hour; however 18 of them (38\%) stated that they could use their tablets just for 30 minutes. 3 of the students (75\%) who could use tablets in one day of a week stated that they could use their tablets for 30 minutes and one of those students $(25 \%)$ stated that they were permitted to use their tablets just for one hour. 3 students $(50 \%)$ who could use their tablets every day pointed that their parents permitted them to use tablets for one hour for each day and 2 of those students (33\%) stated that they could use their tablets for two hours in each day. One of the students in this study noted that there was no restriction for using tablets in terms of duration.

The question of "If there is not a restriction, how many hours do you want to use tablet?" were answered by students in ranging from 30 minutes to 24 hours. 17 of the students $(29 \%)$ answered it as 30 minutes, 11 of them $(19 \%)$ stated that they wanted to use tablets for 1 hour; 6 of them $(10 \%)$ said that 2 hours were enough for them. However, 6 of the students $(10 \%)$ stated that they wanted to play with their tablets for 24 hours. 


\subsubsection{Reading e-Books on Tablets}

It was realized that 61 of the students (97\%) liked reading books. 29 of the students (46\%) stated that they wanted to read books on their tablets, whereas 34 of the students (54\%) pointed that they do not like reading e-books. More than half of the students noted that they liked reading printed books and e-books.

\subsubsection{Playing Preferences}

The question "do you prefer playing in playgrounds if there are playgrounds near your houses or do you prefer playing games with your tablets?" was answered by students as follows; 45 of the students $(71 \%)$ stated that they preferred playing in playgrounds, however 18 of them (29\%) stated that they preferred with their table.

\subsection{The Students' Aims of Using Tablets}

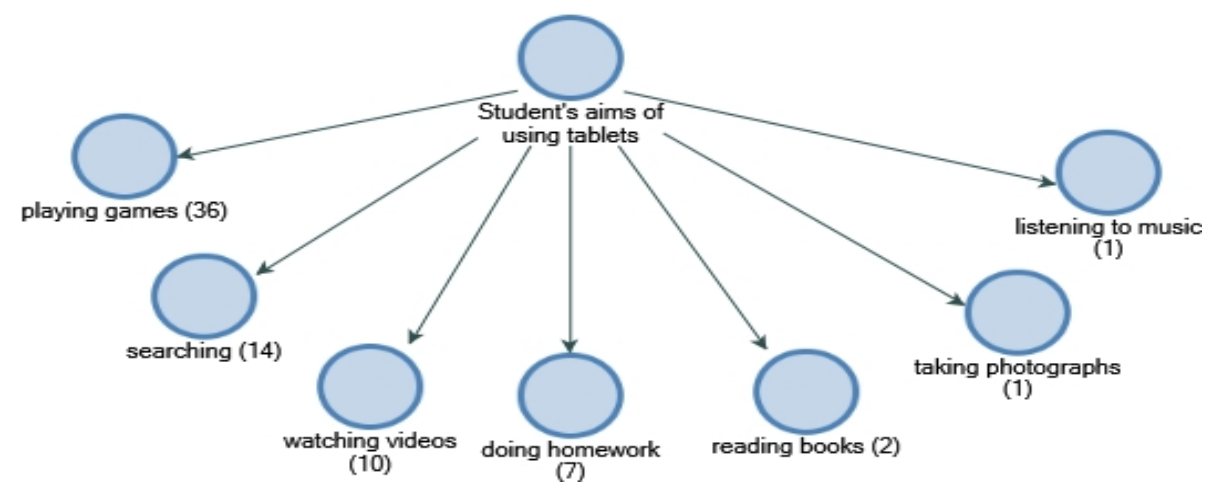

Figure 1. The aims of students for using tablets

According to this figure, the students mostly used their tablets for playing games, and then they used it for searching, watching videos and doing homework. They rarely used tablets for reading book, listening to music and taking photographs.

\subsection{The Metaphors of students for Tablets}

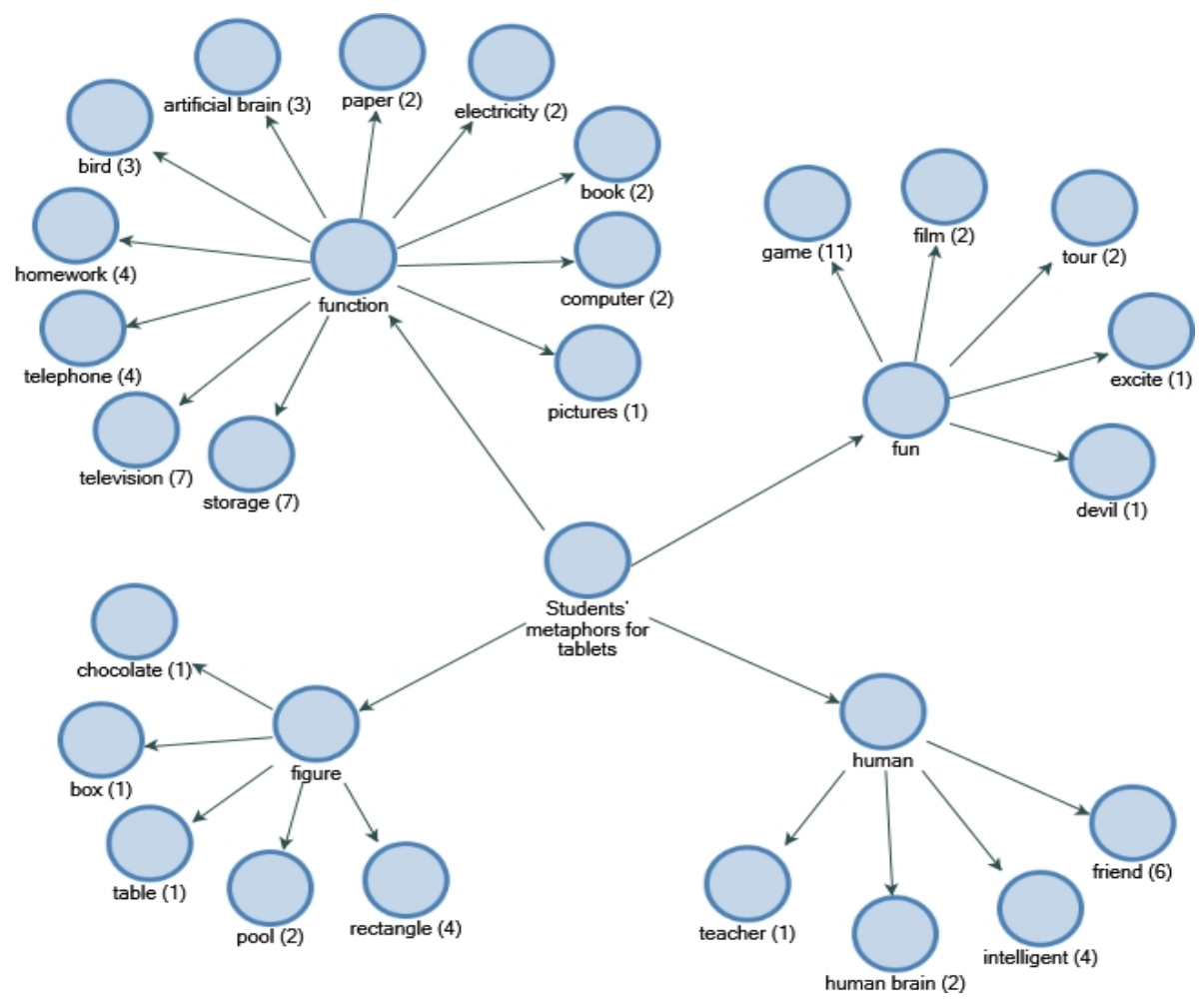

Figure 2. The students' metaphors for tablets 
As it is seen on Figure 2, the students' metaphors for tablets were generalized under the themes namely Function, Figure, Human and Fun. Under the main theme of function, the objects which are similar to tablets; under the main theme of Figure, general simulations for rectangle or square; under the theme of Human, some similarities of properties of human beings and tablets; and finally under the theme of fun, the metaphors for funny usage of tablets were mentioned by the students. The codes and sample sentences with related to those themes were given in Table 2.

Table 2. Themes, codes and sample sentences for tablet's metaphors

\begin{tabular}{|c|c|c|}
\hline Theme & Code & Sample Sentences \\
\hline \multirow{4}{*}{ Human } & Friend & $\begin{array}{l}\text { It is near of me when there is not a } \\
\text { friend. It is always with me. }\end{array}$ \\
\hline & İntelligent & $\begin{array}{l}\text { It knows whatever I asked. I can search } \\
\text { with it. }\end{array}$ \\
\hline & Human Brain & $\begin{array}{l}\text { It sometimes is wrong. There is so much } \\
\text { information in it. }\end{array}$ \\
\hline & Teacher & It has much knowledge like a teacher. \\
\hline \multirow{5}{*}{ Figure } & Chocolate & It is similar to a chocolate. \\
\hline & Rectangle & It looks like a rectangle. \\
\hline & Pool & It is similar to a pool. \\
\hline & Table & It is also square. \\
\hline & Box & It has edges and it is long. \\
\hline \multirow{11}{*}{ Function } & Computer & $\begin{array}{l}\text { They are nearly the same. Both of them } \\
\text { need internet. }\end{array}$ \\
\hline & Storage & $\begin{array}{l}\text { All of the games are in it. There are lots } \\
\text { of thing in tablets. }\end{array}$ \\
\hline & Telephone & $\begin{array}{l}\text { They are nearly the same things. If } \\
\text { tablets are smaller, it is similar to } \\
\text { telephones. }\end{array}$ \\
\hline & Television & $\begin{array}{l}\text { It has a got a screen like TV. I can watch } \\
\text { films on tablet. }\end{array}$ \\
\hline & Paper & $\begin{array}{l}\text { I can write and draw with both of them. I } \\
\text { can draw or write on tablets. }\end{array}$ \\
\hline & Book & $\begin{array}{l}\text { It has many things. Because it is very } \\
\text { knowledgeable }\end{array}$ \\
\hline & Bird & $\begin{array}{l}\text { It is very light and its color is similar to a } \\
\text { bird. It can go everywhere like a bird. }\end{array}$ \\
\hline & Homework & I can search. I can do homework. \\
\hline & Pictures & I can change backstage. \\
\hline & Electricity & $\begin{array}{l}\text { Both of them can reach us in a short } \\
\text { way. Both of them have cables. }\end{array}$ \\
\hline & $\begin{array}{l}\text { Artificial } \\
\text { Brain }\end{array}$ & $\begin{array}{l}\text { It makes our lives easier. It is very } \\
\text { intelligent. }\end{array}$ \\
\hline \multirow{4}{*}{ Fun } & Film & There are nice films. I watch films. \\
\hline & Tour & $\begin{array}{l}\text { I can travel from worlds. I can travel } \\
\text { with it. }\end{array}$ \\
\hline & Excite & It makes me excited. \\
\hline & Game & $\begin{array}{l}\text { I can play with it. There are many games } \\
\text { in it. There are games in tablets. }\end{array}$ \\
\hline
\end{tabular}

\section{Discussion and Suggestions}

The data collected during the study was introduced in this session and there were some suggestions, too. In the study that was conducted with the second grade students in primary schools, the positions of students in terms of using tablet and their metaphors for using tablets were revealed.

It was found that 56 of the students who were participated in this study had tablets at home and they could install some applications. This result indicated that the rate of having a tablet was high for students and they highly used tablets. The study had similar finding with the study by Goh, Bay and Chen [31] in terms of students' high levels of access to tablets.

The restrictions of parents were based on days and duration. In general, students were permitted to use tablet and the duration of using tablets ranged from 30 minutes to 1 hour. In study conducted by Goh, Bay and Chen [31], it was seen that $83 \%$ of students need to get permission from their parents to use tablets; and the constraints of using tablets were based on "Do not play for long time" and "You can play with it after you finish your homework". If there is not a restriction, more than half of the students wanted to use tablets for 30 minutes to 2 hours. This situation reveals that the students adopt the restrictions that are determined by their parents.

Nearly all of the students noted that they liked reading books. However, it was seen that nearly half of the students like reading books on their tablets, and half of them like reading printed books. In order to make a balance on reading skills, it is thought that delivering course books in a printed version instead of totally digital ones and supplying supportive resources for reading skills on tablets can be a good solution for the equilibrium. In many studies, it has been realized that there has been a mean relationship between obesity, low school performance, problems on interaction with peers, low level of reading book, attention problems, addictiveness, lack of learning and the duration of using digital devices $[32,33]$. For this reason, it will be more suitable that there should have a plan for using tablets in terms of duration.

When the students' playing preferences were examined, it was seen that the students mostly preferred playing the playgrounds with their friends instead of playing with tablets. The reason of this situation may be explained as there has not been addictiveness for using tablets because of the restrictions determined by parents.

The students use their tablets for mostly playing games. Apart from this, they use it for the aim of searching, watching videos, doing homework, reading books, listening to music and taking photographs. In the study conducted by Goh, Bay and Chen [31], the similar findings were revealed.

Based on the results, it can be said that the students have a positive perception for tablet. In many studies $[9,11,34,13]$, similar findings were revealed. These positive perceptions are important for technology integration to classrooms. The fact that students have positive perceptions is closely related to their attitudes towards tablet. In this context, findings of the research support many researches' findings in which students have a positive attitude toward tablet $[35,11,36,18$, 37]. As Çakır and Yıldırım [38] stated, the attitudes of 
students towards technology are one of the key factors for technology integration in classroom.

Presenting a variety of reasons to use tablets, students emphasized important directions for teachers, local/national educational authorities, and parents. Teachers, first of all, can integrate tablet based teaching methods and techniques more apparently. Therefore, students' positive attitudes and interests can be transferred into educational purposes. Teachers as learning environment mediators can enhance learning outcomes both academically and individually for the students. By applying technology agents as tablets in classroom environment, teachers draw students' attention to course objectives, learning procedure, and evaluation and feedback sessions, which means keeping students "alive" during instructional time. Besides, students can be attached to out-of-classroom activities via tablets, reinforcing their attitudes. Therefore, learning procedure can be also transferred to anytime anywhere students would like to be in.

Considering local/national educational authorities policies in technology integration, in school environment, it can be said that positive effects of such policies are possible to be observed even in younger ages. These policies as FATIH Project, can be advanced in even primary education level to contribute learning activities and outcomes. However, enriching only students with tablets or any other technological agents is not solely enough to improve educational settings. Teachers should also be involved in the procedure professionally and motivated to learn new teaching techniques for tablet use via seminars, workshops and etc. Particularly curriculum designers should collaborate with technologist to enrich primary education context and develop applications for tablet use for near future.

Since parents are not able to restrain their children from using tablets in such a digital age, they can turn the situation into an advantage. They can be models for their children to exemplify how a tablet can be used for learning purposes by stimulating. They can use tablets as reinforcers for positive manners and behaviors in social environment.

To sum up, for the study as a whole, it can be said that students are ready to work with tablets in classroom regarding their positive perceptions and active use of tablets. Additionally these perceptions can be benefitted for teachers, educational local/national authorities, and parents. For further contributions, similar studies, which will be carried out in rural areas, can be conducted for the field. On the other hand, the reasons of restrictions determined by the parents are not known very well. The studies, which will be aimed to reveal these reasons for restrictions, can be helpful for the field. The limited number of participants, not having a tablet of all students and the low level of generalizability of the results can be seen as the limitations of the study.

\section{REFERENCES}

[1] Gartner. (2015). Gartner says worldwide device shipments to grow 1.5 percent, to reach 2.5 billion units in 2015 . Retrieved form http://www.gartner.com/newsroom/id/3088221.

[2] Statista. (2016). Shipment forecast of laptops, desktop PCs and tablets worldwide from 2010 to 2019 (in million units). Retrieved from

http://www.statista.com/statistics/272595/global-shipments-f orecast-for-tablets-laptops-and-desktop-pcs/.

[3] Palaiologou, I. (2014). Children under five and digital technologies: implications for early years pedagogy. European Early Childhood Education Research Journal, 1807(July), 120. doi:10.1080/1350293X.2014.929876

[4] Weitz, R. R., Wachsmuth, B., \& Mirliss, D. (2006). The tablet PC for faculty: A pilot project. Educational Technology \& Society, 9(2), 68-83.

[5] Haßler, B., Major, L., \& Hennessy, S. (2016). Tablet use in schools: A critical review of the evidence for learning outcomes. Journal of Computer Assisted Learning, 32 (2), 139-156. doi:10.1111/jcal.12123.

[6] Jenni, R. \& Mikko, V. (2013). Actual and potential pedagogical use of tablets in schools. Human Technology, 9(December), 113-131. doi:10.17011/ht/urn.201312042736.

[7] Ifenthaler, D. \& Schweinbenz, V. (2013). The acceptance of Tablet-PCs in classroom instruction: The teachers' perspectives. Computers in Human Behavior, 29 (3), 525-534. doi:10.1016/j.chb.2012.11.004.

[8] Akcaoglu, M., Gumus, S., Bellibas, M. S., \& Boyer, D. M. (2015). Policy, practice, and reality: Exploring a nation-wide technology implementation in Turkish schools. Technology, Pedagogy and Education, 24(4), 477-491. doi:10.1080/1475939X.2014.899264

[9] Couse, L. J. \& Chen, D. W. (2010). A tablet computer for young Children? Exploring its viability for early childhood education. Journal of Research on Technology in Education, 43 (1), 75-98. doi:10.1016/j.compedu.2010.07.018

[10] Çetinkaya, L. \& Keser, H. (2014). Öğretmen ve öğrencilerin tablet bilgisayar kullanımında yaşadıkları sorunlar ve çözüm Önerileri. Anadolu Journal of Educational Sciences International, 4 (1), 13-34.

[11] Dundar, H. \& Akcayir, M. (2014). Implementing tablet PCs in schools: Students' attitudes and opinions. Computers in Human Behavior, 32, 40-46. doi:10.1016/j.chb.2013.11.020

[12] Fekonja-Peklaj, U. \& Marjanovič-Umek, L. (2015). Positive and negative aspects of the IWB and tablet computers in the first grade of primary school: a multiple-perspective approach. Early Child Development and Care, 185 (6), 996 - 1015. doi:10.1080/03004430.2014.974592

[13] Li, S. C., Pow, J. W. C., Wong, E. M. L., \& Fung, A. C. W. (2010). Empowering student learning through Tablet PCs: A case study. Education and Information Technologies, 15(3), 171-180. doi:10.1007/s10639-009-9103-2

[14] Mouza, C. (2005). Using technology to enhance early childhood learning: The 100 days of school project. Educational Research Evaluation, 11(6), 513-528. doi:10.1080/13803610500254808

[15] Ditzler, C., Hong, E., \& Strudler, N. (2016). How tablets are utilized in the classroom. Journal of Research on Technology in Education, 48 (3), 181-193. doi:10.1080/15391523.2016.1 172444 
[16] Kirschner, P. \& Erkens, G. (2006). Cognitive tools and mindtools for collaborative learning. Journal of Educational Computing Research, 35 (2), 199-209. doi:10.2190/R783-230M-0052-G843

[17] Hew, K. F. \& Brush, T. (2007). Integrating technology into K-12 teaching and learning: Current knowledge gaps and recommendations for future research. Educational Technology Research and Development, 55 (3), 223 - 252. doi:10.1007/s11423-006-9022-5

[18] Pruet, P., Ang, C. S., \& Farzin, D. (2015). Understanding tablet computer usage among primary school students in underdeveloped areas: Students' technology experience, learning styles and attitudes. Computers in Human Behavior, 55, 1131-1144. doi:10.1016/j.chb.2014.09.063

[19] FATIH Project. (2016). Tablet. Retrieved from http://fatihprojesi.meb.gov.tr/en/?page_id=145

[20] Dundar, H. \& Akcayir, M. (2012). Tablet vs. paper: The effect on learners' reading performance. International Electronic Journal of Elementary Education, 4 (3), 441-450.

[21] Picard, D., Martin, P., \& Tsao, R. (2014). iPADS at school? A quantitative comparison of elementary school children's pen-on-paper versus finger-on-screen drawing skills. Journal of Educational Computing Research, 50 (2), 203 - 212. doi:10.2190/EC.50.2.c

[22] Davis, L. L., Orr, A., Kong, X., \& Lin, C.-H. (2015). Assessing student writing on tablets. Educational Assessment, 20(3), 180-198. doi:10.1080/10627197.2015.1061426

[23] Al-Mashaqbeh, I. F. (2016). IPad in elementary school math learning setting. International Journal of Emerging Technologies in Learning, 11(2), 48-52. doi:10.3991/ijet.v11i02.5053

[24] Kerawalla, L., Connor, J. O., Underwood, J., Holmberg, J., Luckin, R., Smith, H., \& Keynes, M. (2007). Exploring the potential of the Homework system and tablet PCs to support continuity of numeracy practices between home and primary school. Educational Media International, 44(4), 289-303. doi:10.1080/09523980701680904

[25] Prensky, M. (2001). Digital Natives, Digital Immigrants. On the Horizon, 9 (5), 1-6. doi:10.1108/10748120110424816

[26] Kirschner, P. \& van Merriënboer, J. J. G. (2013). Do learners really know best? Urban legends in education. Educational Psychologist, 48(3), 169-183.

doi:10.1080/00461520.2013.804395
[27] Howley, A., Wood, L., \& Hough, B. (2011). Rural elementary school teachers' technology integration. Journal of Research in Rural Education, 26(9), 1-13. doi:10.1080/13892240802207650

[28] Pittman, T. \& Gaines, T. (2015). Technology integration in third, fourth and fifth grade classrooms in a Florida school district. Educational Technology Research and Development, 63(4), 539-554. doi:10.1007/s11423-015-9391-8

[29] Karasar, N. (2010). Bilimsel araştırma yöntemi (21. edt.). Ankara: Nobel Yayın Dağıtım.

[30] Fraenkel, J. R., Wallen, N. E., \& Hyun, H. H. (2012). How to design and evaluate research in education (8. edt.). Boston, MA: McGraw Hill.

[31] Goh, W. W. L., Bay, S., \& Chen, V. H. H. (2015). Young school children's use of digital devices and parental rules. Telematics and Informatics, 32(4), 787-795. doi:10.1016/j.tele.2015.04.002

[32] Plowman, L., Stevenson, O., Stephen, C., \& McPake, J. (2012). Preschool children's learning with technology at home. Computers \& Education, 59(1), 30-37. doi:10.1016/j.compedu.2011.11.014

[33] Rosen, L. D., Lim, A. F., Felt, J., Carrier, L. M., Cheever, N. A., Lara-Ruiz, J. M., ... Rokkum, J. (2014). Media and technology use predicts ill-being among children, preteens and teenagers independent of the negative health impacts of exercise and eating habits. Computers in Human Behavior, 35, 364-375. doi:10.1016/j.chb.2014.01.036

[34] Eren, E. (2015). Ortaokul ve lise öğrencilerinin eğitimde tablet bilgisayar kullanımına ilişkin algıları ile görüşleri. Ahi Evran Üniversitesi Kırşehir Eğitim Fakültesi Dergisi (KEFAD), 16(1), 409-428.

[35] Batur, Z., Gülveren, H., \& Balcı, S. (2013). An empirical work about the attitudes of students receiving education under "tablet pc pilot practice" towards use of technology in Turkish lectures. European Journal of Educational Studies, 5(1), 29-42.

[36] Kenar, İ. (2012). Teknoloji ve derslerde teknoloji kullanımına yönelik veli tutum ölçeği geliştirilmesi ve tablet PC uygulaması. Eğitim Bilimleri Araştırmaları Dergisi, 2(2), 123-139.

[37] Tekerek, M., Altan, T., \& Gündüz, I. (2014). FATİH projesinde tablet PC kullanımına yönelik öğrenci tutumlarının incelenmesi. Bilişim Teknolojileri Dergisi, 7 (2), 21-27. doi:10.12973/bid.2017

[38] Çakır, R. \& Yildırım, S. (2009). What do computer teachers think about the factors affecting technology integration in schools? Elementary Education Online, 8 (3), 952-964. 